\title{
Utilization of Halophytes as a source of organic Manure
}

\author{
D. Ayyappan, K. C. Ravindran* \\ Department of Botany, Annamalai University, Annamalai Nagar - 608 002, India \\ *E-mail address: drkc_ravi@rediffmail.com
}

\begin{abstract}
Organic farming is a holistic production management system that promotes and enhances environmental quality including biodiversity, bio-geo-chemical cycles and soil floral and faunal activities. One of the energy resources developed during recent years are the application of organic sources such as biogas slurry, blue green algae, compost, green manure farmyard manure, vermicompost and seaweed liquid fertilizer. During decomposition, these organic manures yield many organic compounds and organic acids as well as antibiotic substances as an intermediate product. Mangrove/Halophytes forest has an important ecological and socio economic value to man. In India, Tamil Nadu has a coastline of $950 \mathrm{~km}$. Extensive mangrove wetlands are located in Pichavaram of Cuddalore district and Muthupet of Thanjavur district. It is reported that the nutrient values of halophytes were higher when compared to green manures (glycophytes). The objective of the present study is to highlight the efficacy of halophytic compost which are normally available in coastal areas on growth and yield parameters in pulse varieties. Various combinations of halophytic composts used, Suaeda compost + farmyard manure + phosphate solubilising bacteria treatment showed an increased in biomass and yield, number of root nodules and microbial activities when compared other halophytic compost and control. This study shows the feasibility of using halophytic composts in the coastal area to improve soil fertility and productivity.
\end{abstract}

Keywords: Halophytes; Compost; Farmyard manure; Vermicompost; Suaeda maritima

\section{INTRODUCTION}

Organic farming is a holistic production management system that promotes and enhances environmental quality including biodiversity, bio-geo-chemical cycles and soil floral and faunal activities. Organic farming methods are widely used in under developed and developing countries, largely because of economics and lack of chemicals. However, they are becoming more widely accepted in developed countries. Organic farming is known by different names in different countries and it is estimated nearly 16 different terms are in usage including biological farming and sustainable farming. One of the energy resources developed during recent years are the application of organic sources such as biogas slurry (Singh and Kumar, 2002), blue green algae (Kannaiyan, 2002), compost (Parasuraman et al., 2003), green manure (Kalpana and Balasubramanian, 2000) farmyard manure (Patil et al., 2003), 
vermicompost (Chinnamuthu and Venkatakrishnan, 2001) and seaweed liquid fertilizer (Sivasankari et al., 2006).

During decomposition, these organic manures yield many organic compounds and organic acids as well as antibiotic substances as an intermediate product. They help to control certain fungal pathogens and nematode infestations. These products on adsorption by plants increase their resistance to some diseases and pests.

\section{MANGROVES/HALOPHYTES}

Mangrove/Halophytes forest has an important ecological and socio economic value to man (Agoramoorthy et al., 2008). In India, Tamil Nadu has a coastline of $950 \mathrm{~km}$. Extensive mangrove wetlands are located in Pichavaram of Cuddalore district and Muthupet of Thanjavur district. The Pichavaram mangrove wetland is located in the northern extreme of the Cauvery delta, near the mouth of river coleroon. Its total area is about 1350 ha and 13 true mangrove species and 20 species of halophytic herbs and shrubs occur naturally in this salt marsh habitat.

Cuevas (1997) records the nutrient values of halophytes and observed that nutrient content in halophytes were higher when compared to green manures (glycophytes), while obtained from some species such as Crotalaria juncea, Sesbania aculeate, Cyamopsis tetragonoloba and Vigna catajung. Halophytes accumulate $\mathrm{NaCl}$ in their tissues. However, when halophytes are subjected to composting, it is possible that $\mathrm{NaCl}$ content present in the tissues will degrade during decomposition. $\mathrm{Na}^{+}$in $\mathrm{NaCl}$ may chelate with the organic acids produced during decomposition and release the $\mathrm{Cl}^{-}$resulting in the reduction of $\mathrm{NaCl}$ content in the plant tissues. Watson (2003) also stated that leaching the compost with water reduce the concentration of soluble salts.

Dahama (1997) recorded the nutrient values (Table. 1) of glycophytes and halophytes and observed that nitrogen content was the maximum when compared to phosphorus and potassium. Cuevas (1997) recorded the nutrient values of mangroves and it is observed that when compared to green manure, the nutrient status of halophytes will be higher.

Table 1. Nutrient status of green manure and halophytes.

\begin{tabular}{|c|c|c|c|c|}
\hline S. NO & Nutrient Sources & N (\%) & P (\%) & K (\%) \\
\hline 1. & Vigna catajung & 0.71 & 0.15 & 0.58 \\
\hline 2. & Sesbania aculeata & 0.62 & - & - \\
\hline 3. & Vigna radiata & 0.72 & 0.18 & 0.53 \\
\hline 4. & Crotalaria juncea & 0.75 & 0.12 & 0.51 \\
\hline 5. & Vigna mungo & 0.85 & 0.18 & 0.53 \\
\hline 6. & Dolichos biflorus & 0.33 & - & - \\
\hline 7. & Farm compost & 2 & 1.9 & 2.9 \\
\hline 8. & Halophytes & 1.50 to 2.30 & 0.13 to 0.76 & 1.30 to 2.03 \\
\hline \multicolumn{7}{|c|}{ Nutrient composition in green manure and halophytes (Dhana, 1997) } \\
\hline
\end{tabular}




\section{CULTIVATION OF HALOPHYTES FOR COMPOST PREPARATION}

Viable seeds/cuttings of selected halophytes were collected from Pichavaram mangrove forest. Seeds were washed with water and mixed with ash and sown immediately in seed beds. The seed beds were made on the ground but raised above the ground level. The size of the seedbed was $1.3 \mathrm{~m}$ wide and 9 to $\mathrm{m}$ long. The seeds/cuttings were scattered evenly on the surface of the bed. Plots were sufficiently watered periodically. Care was taken to maintain the halophytes free from any nutrient deficiency or infection.

\section{1. Steps in Composting}

Three months of healthy halophytes were harvested from nursery and used for preparation of compost. The plant materials as well as rice straw were chopped well. The substrates were piled loosely in a chopped pen to provide better aeration within the heap. The material was too compact and no heavy weights were put on top. Compost heaps was located in shady areas. The platform was raised about $30 \mathrm{~cm}$ from the ground, to provide adequate aeration at the bottom. Alternatively, aeration was provided by placing perforated bamboo trunks horizontally and vertically at regular intervals, to carry air through the compost heap. The inoculation of fungus Pleurotus sajor-caju (Fr.) Singer, was added to the compost heap for best decomposition. The amount of activator used was usually $1 \%$ of the total weight of the substrates (Cuevas, 1997).

The heap was covered over completely. This maintained the heat of decomposition and minimized water evaporation and ammonia volatilization. White plastic sheets were used as a cover. Temperature readings were taken at different parts of the pile at least three times a week. Heat was maintained at $50{ }^{\circ} \mathrm{C}$ or higher and the heap was turned over every 5-7 days for the first two weeks and thereafter once every two weeks. Turning over the pile provided adequate aeration and evened up the rate of decomposition throughout the pile. By the end of the third month, the compost was ready to use. It was dark brown, crumbly and had an earthy aroma.

\section{REDUCTION OF NaCI AFTER COMPOSTING}

From Table 2, it is observed that the presence $\mathrm{NaCl}$ concentrations are drastically reduced, when these halophytes are subjected under decomposition.

Table 2. It observation reducing content $\mathrm{NaCl}$.

\begin{tabular}{|c|c|c|c|c|c|c|}
\hline \multirow{3}{*}{ Plants } & \multicolumn{4}{|c|}{ mg/g. fr. wt } & \multicolumn{2}{c|}{ Reduction (\%) } \\
\cline { 2 - 7 } & \multicolumn{2}{|c|}{$\begin{array}{c}\text { Before } \\
\text { composting }\end{array}$} & \multicolumn{2}{c|}{ After composting } & \multicolumn{2}{c|}{} \\
\cline { 2 - 7 } & $\mathrm{Na}$ & $\mathrm{Cl}$ & $\mathrm{Na}$ & $\mathrm{Cl}$ & $\mathrm{Na}$ & $\mathrm{Cl}$ \\
\hline Ipomoea & 24 & 18.0 & 10 & 9.0 & 41.7 & 50.0 \\
\hline Sesuvium & 22 & 16.5 & 9.0 & 8.0 & 40.9 & 48.5 \\
\hline Suaeda & 20 & 15.0 & 7.5 & 6.6 & 37.5 & 44.0 \\
\hline
\end{tabular}




\section{APPLICATIONS OF HALOPHYTIC COMPOST}

Halophytic compost has been identified as an alternative to chemical fertilizer to increasing soil fertility and crop production in sustainable farming. Ravindran et al. (2007) observed in Arachis hypogaea halophytic compost along with farmyard manure and phosphate solubilising bacteria resulted in production of highest biomass and root nodules. Balakrishnan et al. (2007) observed that halophytic compost significantly increased the soil micro flora and enzyme activities in Arachis hypogaea cultivated soil. Recently, Ayyappan et al. (2013) observed that halophytic compost increased the growth and yield characteristics of Vigna radiata in salt affected agricultural land at coastal area.

\section{CONCLUSION}

Results of the present study indicate the feasibility of using halophytic composts in the coastal area to improve soil fertility and productivity.

\section{References}

[1] Agoramoorthy G., F. A. Chen M. J. Hsu,. Environ. Poll 155 (2008) 320-326.

[2] Ayyappan D., K. Sanjiviraja V. Balakrishnan, K. C. Ravindran, African Journal of Agricultural Research 8(22) (2013) 2663-2673.

[3] Balakrishnan V., K. Venkatesan, K. C. Ravindran, Plant. Soil. Environ 53(4) (2007) 186-192.

[4] Chinnamuthu C. R., A. S. Venkatakrishnan, Madras Agric. J. 85(10-12) (2001) 683685 .

[5] Cuevas V. C, Food. Fert. Technol. Centre Extn. Bull 444 (1997) 1-13.

[6] Dahama A. K, Agro Botanica, (1997) 119.

[7] Kalpana R., A. Balasubramanian, Madras. Agric. J. 87(1-3) (2000) 93-95.

[8] Kannaiyan S. (2002). Biofertilizers for sustainable crop production. In: Biotechnology of biobertilizers, S. Kannaiyan (Ed.). Narosa Publishing House, New Delhi, India, pp. 9-49.

[9] Parasuraman P., A. K. Mani, M. Suresh, Agric. J. 90(4-6) (2003) 232-235.

[10] Patil P. V., P. B. Chalwade A. S. Solanke V. K. Kulkarni, J. Soils ans Crops 13(1) 2003) 59-64.

[11] Ravindran K. C., K. Venkatesan, T. Balasubramanian, V. Balakrishnan, Science of the total environment 384 (2007) 333-341.

[12] Singh B., A. Kumar, Indian. J. Agric. Chem. 35(1) (2002) 41-44. 
[13] Sivasankari S., V. Venkatesalu, M. Anantharaj, M. Chandrasekaran (2006). Effect of seaweed extracts on the growth and biochemical constituents of Vigna sinensis. Bioresour. Techniol (In press).

[14] Watson M. E. (2003). Testing compost. Extension Fact Sheet, School of Natural Resources, Coumbus, OH, pp. 1-14. 